\title{
THE HISTO-ANATOMICAL INVESTIGATION AND THE POLYPHENOLIC PROFILE OF ANTIOXIDANT COMPLEX ACTIVE INGREDIENTS FROM THREE VIOLA SPECIES
}

\author{
TÜNDE JURCA ${ }^{1}$, ANNAMARIA PALLAG $^{1 *}$, ELEONORA MARIAN ${ }^{1}$, MARIANA EUGENIA \\ MUREȘAN ${ }^{1}$, ROXANA LIANA STAN ${ }^{2}$, LAURA GRAȚIELA VICAȘ ${ }^{1}$ \\ ${ }^{1}$ University of Oradea, Medicine and Pharmacy Faculty, Department of Pharmacy, 29 Nicolae Jiga Str., 410028, Oradea, Romania \\ ${ }^{2}$ Department of Pharmaceutical Biochemistry and Clinical Laboratory, Faculty of Pharmacy, University of Medicine and \\ Pharmacy „Iuliu-Hațieganu” Cluj-Napoca, 400012, Romania
}

*corresponding author: annamariapallag@gmail.com

Manuscript received: October 2018

\begin{abstract}
In the present study three edible species of the Violaceae family (Viola odorata L., Viola tricolor L. and Viola wittrockiana Gams.) were screened in order to assess their morphological and anatomical characteristics, their polyphenolic contents and their antioxidant activities. The dried herbal drugs were lyophilized and underwent pre-treatment for high pressure liquid chromatography. Thus 6 flavonoids and 6 phenolic acids were quantitatively determined. Antioxidant activity was evaluated using several methods: FRAP (ferric reducing antioxidant power), DPPH (2,2-diphenyl-1-picrylhydrazyl) and CUPRAC (cupric ion reducing antioxidant capacity) assay. The polyphenolic profile revealed the presence of common components between species such as rutin, myricetin, p-coumaric acid, ferulic acid, sinapic acid, vanillic acid and other compounds such as catechin, luteolin, epicatechin, naringenin, syringic acid and caffeic acid, specific only in some of the studied species.
\end{abstract}

\section{Rezumat}

În acest studiu am caracterizat trei specii aparținând familiei Violaceae (Viola odorata L., Viola tricolor L. și Viola wittrockiana Gams.) din punct de vedere morfologic, anatomic, al conținutului de polifenoliși a capacității antioxidante. Florile uscate au fost supuse liofilizării, după care s-au pregătit extractele pentru analiza HPLC. Astfel, s-au determinat cantitativ 6 flavonoide şi 6 acizi fenolici. Activitatea antioxidantă s-a studiat prin tehnicile FRAP, DPPH și CUPRAC. Dintre polifenoli s-au identificat câteva componente comune pentru toate trei speciile, respectiv rutinul, miricetina, acidul pcumaric, acidul ferulic, acidul sinapic, acid vanilic, dar și compuși fenolici ce diferă de la o specie la alta, precum catechina, luteolina, epicatechina, naringenina, acidul siringic și acidul cafeic.

Keywords: Viola odorata L., Viola tricolor L., Viola wittrockiana Gams., phenolic acids, flavonoids, DPPH, CUPRAC, FRAP

\section{Introduction}

Phenolic compounds, ubiquitous in plants, are of considerable interest and have received increased attention in recent years due to their bioactive functions [14]. Polyphenols are among the most desirable phytochemicals due to their antioxidant activity. These components are known as secondary plant metabolites and possess antimicrobial, antiviral and antiinflammatory properties along with high antioxidant capacity $[15,29,35]$.

Plants are well known for their capacity to produce a diverse array of secondary metabolites in order to interact with their environment [36, 40, 43]. The major classes of secondary metabolites are alkaloids, terpenes and polyphenols. The amount and type of polyphenols produced by plants vary considerably between species [5, 6, 13, 16, 18, 32].

Polyphenols are present throughout the plant kingdom as they offer plants protection against UV radiation. These compounds play an important role in plant growth and reproduction induces antibacterial activity and modulates oxidative stress, inflammation and apoptosis in endothelial cell exposed to hyperosmotic stress, as well as contributing to the colour, sensory characteristics and nutritional properties of fruits and vegetables $[17,18]$. Some polyphenols are proposed as therapeutic agents for a variety of diseases or to promote general health $[16,26]$.

The Violaceae family, consisting of 806 species, includes mostly flowering plants. It takes its name from its most known genus, Viola, which includes 450 species. The Romanian flora comprises around 30 species from the genus Viola [3].

Species from genus Viola present rich sources of phytochemical compounds, being involved in plant growth, metabolism and reproduction, as well as providing protection against pathogens and UV radiation [19, 37].

Studies have demonstrated that dietary polyphenols can act as free radical scavengers, by inducing, inhibiting 
or modulating the transduction signal of antioxidant enzymes or by chelating metal ions [8-10, 12].

The purpose of this study was the morphological, histoanatomical, physico-chemical characterization, quantification of the polyphenolic content and antioxidant capacity of three Viola species flowers extracts: Violae odoratae flos, Violae tricoloris flos and Violae wittrockianae flos.

\section{Materials and Methods}

Plant materials

We conducted a comparative study on the species Viola odorata L., Viola tricolor L. and Viola wittrockiana Gams. Viola tricolor L. and Viola odorata L. are found as part of the north western Romanian spontaneous flora, but Viola wittrockiana Gams. is cultivated as an ornamental plant.

Violae odoratae flos and Violae tricoloris flos were collected from the spontaneous flora of Bihor County, Romania, from unpolluted areas in 2017. Violae wittrockianae flos was collected from a cultivated area of Bihor County, in 2017. Microscopic sections were made from the parts of the collected plants.

A specimen from each of the studied species was deposited in the Pharmaceutical Botany Herbarium of the Faculty of Medicine and Pharmacy Oradea, Romania.

Plant materials were dried at room temperature and grounded before extraction.

Extract preparation

$10 \mathrm{~g}$ dried flowers were extracted with $70 \%$ aqueous ethanol $(100 \mathrm{~mL})$, using a magnetic mixer for 45 min and further sonicated for $5 \mathrm{~min}$. The alcohol was evaporated using a rotary evaporator and the dried extract was lyophilized.

Preparation of the plant extract (1)

$50 \mathrm{mg}$ dry (lyophilized) extract was weighed and dissolved in $2 \mathrm{~mL} \mathrm{90 \%} \mathrm{methanol} \mathrm{and} 0.5 \%$ acetic acid mixture. The sample was centrifuged on a rotary evaporator to dryness. The residue was dissolved in $1 \mathrm{~mL}$ DMSO and transferred into a test tube.

Preparation of the plant extract (2)

About $50 \mathrm{mg}$ dry (lyophilized) extract was weighed and dissolved in $4 \mathrm{~mL} \mathrm{25 \%}$ methanol. After addition of $1 \mathrm{~mL}$ of $6 \mathrm{M} \mathrm{HCl}$, the sample was sonicated for $2 \mathrm{~min}$ and mixed in a water bath at $85-90^{\circ} \mathrm{C}$ for $2 \mathrm{~h}$, $2.5 \mathrm{~mL}$ ethylacetate was then added to each sample and this extract was vacuum evaporated to dryness on a rotary evaporator. The residue was dissolved in $1 \mathrm{~mL}$ DMSO and transferred into a test tube.

Analysis of phenolic compounds by HPLC

Pure phenol standards including 6 phenolic acids (caffeic, syringic, sinapic, vanillic, p-coumaric, ferulic) and 6 flavonoids (rutin, naringenin, luteolin, quercetine, epicatechin, myricetin) were dissolved in the mobile phase $(1 \mathrm{mg} / \mathrm{mL})$. The solutions were freshly prepared, filtered through a $0.45 \mu \mathrm{m}$ membrane filter and immediately injected to HPLC column. Evaluation of each sample was repeated three times [20].

We used the Shimadzu SCL-POA reversed-phase high-performance liquid chromatography system in order to assess the phenolic compound content. The system consisted of a LC-10ADVP pump equipped with SPD-10AVP Diode Array (UV) detector. The column type was Kintex 5u RP C18 $\mu \mathrm{m}, 4.6 \mathrm{~mm}$ internal diameter $\times 250 \mathrm{~mm}$. The mobile phase was composed of (A) $0.05 \%$ formic acid and (B) $0.05 \%$ formic acid-acetonitrile, 50:50 v/v. We performed the gradient elution process as follows: $0 \mathrm{~min}, 95: 5$; $10 \mathrm{~min}, 90: 10$; $40 \mathrm{~min}, 60: 40$, $55 \mathrm{~min}, 45: 55$; $60 \mathrm{~min}$, 20:80; and $65 \mathrm{~min}, 0: 100$. The mobile phase was filtered under vacuum through a $0.45 \mu \mathrm{m}$ membrane filter before use. The flow rate was $1.5 \mathrm{~mL} / \mathrm{min}$. UV absorbance was measured at $260-380 \mathrm{~nm}$. The operating temperature was maintained at room temperature. Identification of the phenolic compounds was achieved by comparison with the standards retention times, UV spectra and by calculating the UV absorbance ratios after simultaneous injection of samples and standards. Analyses were performed in triplicate [15, 20, 33, 44, 45].

The bioactive compounds of plant extracts

Determination of polyphenols content

The Folin-Ciocâlteu method was used in order to determine the total phenolic content. Using the FolinCiocâlteu method the $\mathrm{OH}$ groups can be evaluated in an alkaline medium (adjusted with sodium carbonate). The absorbance at $765 \mathrm{~nm}$, increases proportionally with the number of $\mathrm{OH}$ groups of the polyphenols. The extract solution $(0.1 \mathrm{~mL})$ containing $1000 \mu \mathrm{g}$ of the extract was mixed with $46 \mathrm{~mL}$ distilled water in a volumetric flask and $1 \mathrm{~mL}$ Folin-Ciocâlteu (Merck) reagent was added. After $3 \mathrm{~min}, 3 \mathrm{~mL}$ aqueous solution of $2 \% \mathrm{Na}_{2} \mathrm{CO}_{3}$ were added. After incubation for $2 \mathrm{~h}$ at room temperature, the absorbance of each mixture was measured at $765 \mathrm{~nm}$ in a Shimadzu UV-1700 Pharmaspec UV-VIS Spectrophotometer. Results were expressed as mg GAE/g DW (dried weight) [18, 23, 25, 33, 39].

\section{The total flavonoid content}

The total flavonoid content was determined using a colorimetric method described by Kim et al. [23]. $1 \mathrm{~mL}$ sample (containing $0.1 \mathrm{mg} / \mathrm{mL}$ dry substance) was mixed with $4 \mathrm{~mL}$ water and inserted in a $10 \mathrm{~mL}$ volumetric flask. Firstly, $3 \mathrm{~mL} 5 \% \mathrm{NaNO}_{2}$ solution were added, after 5 minutes $-0.3 \mathrm{~mL} 10 \% \mathrm{AlCl}_{3}$ and after 6 minutes - $2 \mathrm{~mL} 1 \mathrm{M} \mathrm{NaOH}$. The solution was mixed and its absorbance was detected at $510 \mathrm{~nm}$. Results were expressed as mg QE/g DW [23, 32, 34, 39, 44].

The antioxidant capacity of flowers extracts Reagents

6-hydroxy-2,5,7,8-tetramethylchroman-2-carboxylic acid (Trolox), Folin-Ciocâlteau's reagent, 2,2-diphenyl1-pycrylhydrazyl (DPPH), 2,4,6-Tris(2-pyridyl)- $s$ - 
triazine (FRAP) were purchased from Sigma Aldrich, USA. Gallic acid and sodium carbonate were purchased from Fluka, Switzerland. All the chemicals used were of analytical grade.

\section{DPPH method}

We determined the free radical scavenging activity of the plant extracts against stable 2,2-diphenyl-1picryl-hydrazyl-hydrate (DPPH), using the slightly modified method of Brand-Williams et al. [2, 4, 30]. The change in colour (from deep violet to light yellow) was measured at $517 \mathrm{~nm}$ using a UV visible light spectrophotometer. The $6 \times 10^{-5}$ methanolic DPPH solution was freshly prepared before each UV measurement. The experiment was carried out in triplicate. Radical scavenging activity was calculated using the following formula:

$$
\% \text { Inhibition }=[(\mathrm{AB}-\mathrm{AA}) / \mathrm{AB}] \times 100,
$$

where, $\mathrm{AB}=$ absorption of the blank sample $(\mathrm{t}=0 \mathrm{~min})$, $\mathrm{AA}=$ absorption of the test extract solution $(\mathrm{t}=15$ $\min )[2,18,31]$.

FRAP method (ferric reducing antioxidant power) $[1,2]$

The stock solutions included: $300 \mathrm{mM}$ acetate buffer; $270 \mathrm{mg} \mathrm{FeCl}{ }_{3} * 6 \mathrm{H}_{2} \mathrm{O}$ dissolved in $50 \mathrm{~mL}$ distilled water; $150 \mathrm{mg}$ TPTZ and $150 \mu \mathrm{L} 40 \mathrm{mM} \mathrm{HCl}$, dissolved in $50 \mathrm{~mL}$ distilled water. We prepared the FRAP solution by mixing $50 \mathrm{~mL}$ acetate buffer, $5 \mathrm{~mL}$ $\mathrm{FeCl}_{3} * 6 \mathrm{H}_{2} \mathrm{O}$ solution and $5 \mathrm{~mL}$ TPTZ solution. We used Trolox as a standard solution. The results are expressed as $\mu \mathrm{mol}$ Trolox equivalents (TE)/100 $\mu \mathrm{L}$ extract.

\section{The CUPRAC assay}

We used the method proposed by Karaman et al. with slight modifications [36] in order to determine the cupric ion $\left(\mathrm{Cu}^{2+}\right)$ reducing antioxidant capacity. We added $0.25 \mathrm{~mL} \mathrm{CuCl}_{2}$ solution $(0.01 \mathrm{M}), 0.25 \mathrm{~mL}$

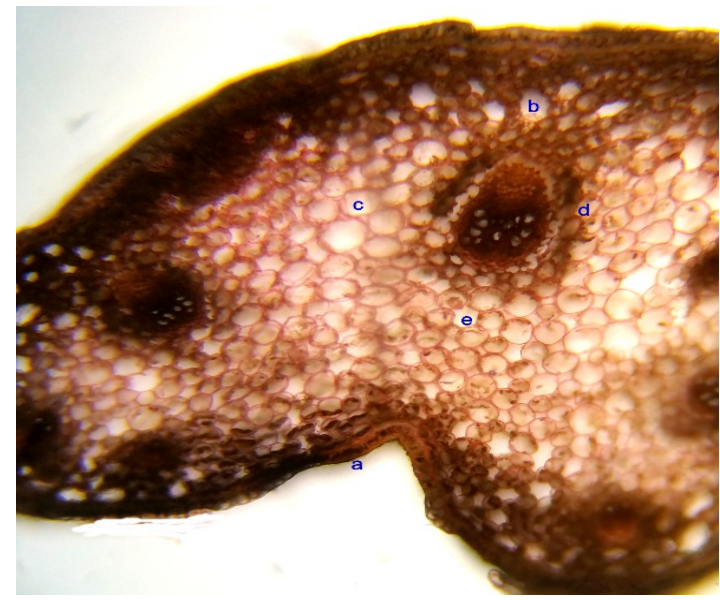

Figure 1.

Cross section through the Viola odorata L. main stem (100X). a - epidermis; b - cortical parenchyma $\mathrm{c}$ - central cylinder parenchyma; $\mathrm{d}$ - vascular bundles; e - central marrow ethanolic neocuproine solution $\left(7.5 \times 10^{-3} \mathrm{M}\right)$ and $0.25 \mathrm{~mL} \mathrm{CH}_{3} \mathrm{COONH}_{4}$ buffer solution $(1 \mathrm{M})$, and mixing the plants extracts. Then, we adjusted the total volume to $2 \mathrm{~mL}$ with distilled water, and mixed thoroughly. We sealed the tubes and kept them at room temperature. Absorbance was measured at $450 \mathrm{~nm}$ against a reagent blank $30 \mathrm{~min}$ later. Increased absorbance of the reaction mixture indicated increased reduction capacity $[39,41]$. The calibration curve was achieved for different concentrations of Trolox.

\section{Results and Discussion}

Morphological and histoanatomical analysis Microscopic sections were made from the collected stems, as shown in Figures 1-5.

Since Viola wittrockiana Gams. have been crossbred from Viola tricolor L., they are believed to possess similar antioxidant activity. Due to its carotenoids, anthocyanins and flavonols content, garden pansies may represent a promising source of natural antioxidants [8, 26, 42]. Attractive flowers and antioxidant capacity enable the garden pansies to become suitable candidates as functional food products $[8$, $15,42]$.

Regarding Viola tricolor L., the main stem has 5 edges, as shown in Figure 2. Throughout the edges, the collenchyma tissue is not well represented in comparison with Viola wittrockiana Gams (Figure 4 and 5), in which the main stem has 4 edges.

The central cylinder begins with a pericycle. In the fundamental parenchyma of the marrow there are numerous vascular bundles, all arranged in a circle. The central cylinder Viola tricolor L., there are more than 10 vascular bundles present. The central cylinder of Viola wittrockiana Gams. has 4 vascular bundles, placed symmetrically.

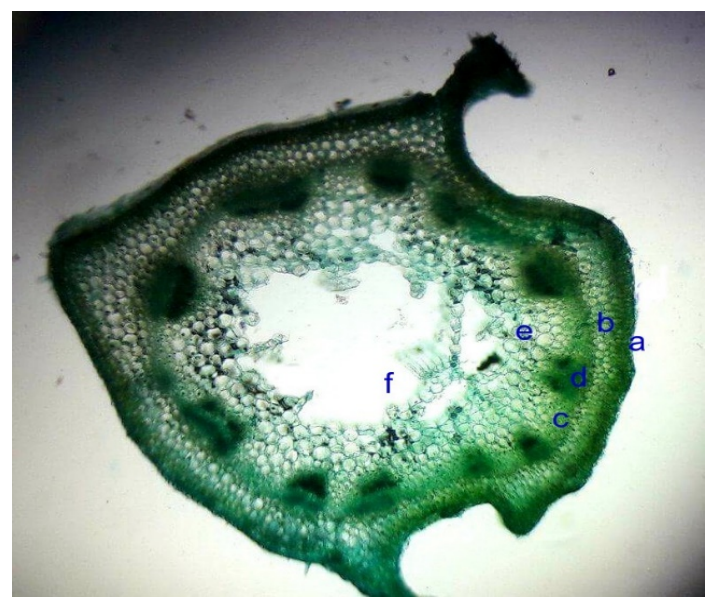

Figure 2.

Cross section through the Viola tricolor L. main stem (100X). a - epidermis; b - cortical parenchyma; c - pericycle; d - vascular bundles; e - central cylinder parenchyma; $\mathrm{f}$ - main gap marrow 


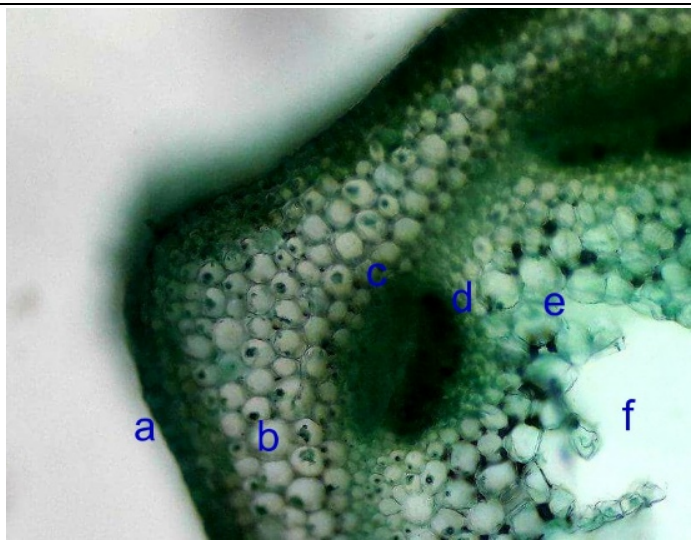

Figure 3.

Cross section through the Viola tricolor L. main stem (200X). a - epidermis; b - storage parenchyma; c phloem tissue; $\mathrm{d}$ - xylem tissue; e - central cylinder parenchyma; f - main gap marrow

The main marrow gap is larger in Viola wittrockiana Gams., than in Viola tricolor L., in which the central marrow tissue is present around the main marrow

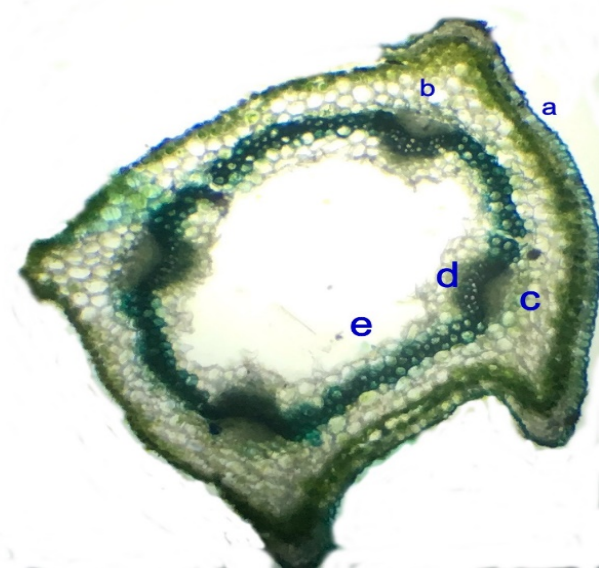

Figure 4.

Cross section through the Viola odorata L. main stem (100X). a - epidermis; b - cortical parenchyma;

c - central cylinder parenchyma; d - vascular bundles; e - central marrow

Content of flavonoids and phenolic acids

HPLC-RP with UV detection was used to identify and quantify the phenolic and flavonoid compounds from the Viola species lyophilized extract. Chromatograms of the Viola species were determined at 270, 310 and $360 \mathrm{~nm}$.

Each sample was analysed after two different types of extractions were performed, in order to obtain exact data regarding flavonoids and phenolic acids, and to estimate the nature of the respective compounds. Total phenols generally correlate with redox and antioxidant capacities, as measured by the TEAC or DPPH methods. gap. In Viola odorata L., the central marrow tissue occupies the centre of the marrow (Figure 1).

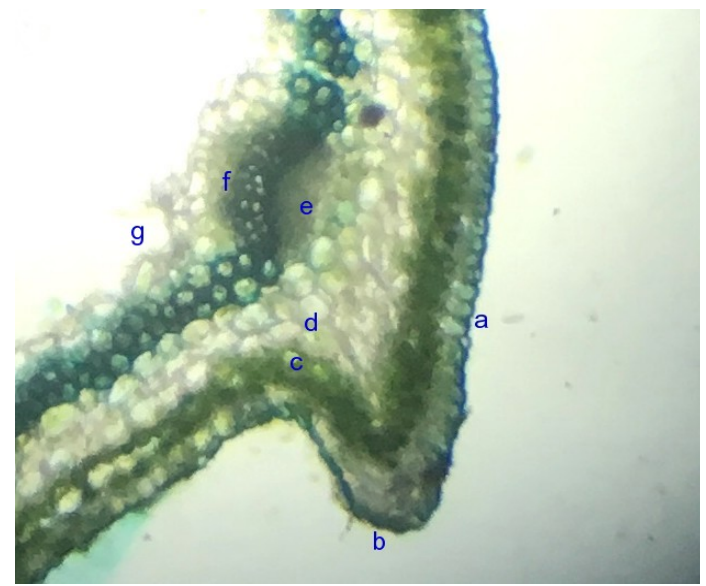

Figure 5.

Cross section through the Viola wittrockiana Gams. main stem (200X). a-epidermis; b - collenchyma; c assimilated cortical parenchyma; d- storage parenchyma; e - phloem tissue; f - xilem tissue; g - main gap marrow

The polyphenolic compounds identified in the analysed samples are presented in Table I.

Four glycosides (epicatechin, catechin, rutin and myricetin) were identified after the first extraction, and from the phenol derivates, four compounds (sinapic acid, p-coumaric acid, ferulic acid, vanillic acid). Ferulic acid was the most abundant phenolic acid for Viola witrockiana Gams. (129.89 $\mathrm{mg} / \mathrm{Kg}$ ) and the predominant flavonoid was myricetin $(131.89 \mathrm{mg} / \mathrm{Kg})$. Regarding flavonoids, the predominant compound in Viola odorata L. and Viola tricolor L. was myricetin and rutin $(84.67 \mathrm{mg} / \mathrm{Kg}, 89.67 \mathrm{mg} / \mathrm{Kg})$. 
Content of flavonoids and phenolic acids determined in Viola species flowers

\begin{tabular}{|c|c|c|c|c|c|c|c|c|}
\hline \multirow{2}{*}{$\begin{array}{l}\text { Bioactive } \\
\text { compounds }\end{array}$} & \multirow{2}{*}{$\frac{\lambda_{\max }}{\mathrm{nm}}$} & \multirow{2}{*}{$\begin{array}{c}\mathbf{R}_{\mathrm{T}} \\
(\mathrm{min})\end{array}$} & \multicolumn{2}{|c|}{ Viola odorata L. } & \multicolumn{2}{|c|}{ Viola tricolor $\mathrm{L}}$. & \multicolumn{2}{|c|}{ Viola wittrockiana Gams. } \\
\hline & & & $\begin{array}{c}\text { Extract } 1 \\
(\mathrm{mg} / \mathrm{kg})\end{array}$ & $\begin{array}{c}\text { Extract } 2 \\
(\mathrm{mg} / \mathrm{kg})\end{array}$ & $\begin{array}{c}\text { Extract } 1 \\
(\mathrm{mg} / \mathrm{kg})\end{array}$ & $\begin{array}{c}\text { Extract } 2 \\
(\mathrm{mg} / \mathrm{kg})\end{array}$ & $\begin{array}{c}\text { Extract } 1 \\
(\mathrm{mg} / \mathrm{kg})\end{array}$ & $\begin{array}{c}\text { Extract } 2 \\
(\mathrm{mg} / \mathrm{kg})\end{array}$ \\
\hline Epicatechin & 280 & 10.82 & $22.21 \pm 0.32$ & $11.34 \pm 0.84$ & - & - & $93.67 \pm 3.35$ & $87.56 \pm 1.37$ \\
\hline Luteolin & 345 & 18.27 & - & $20.56 \pm 0.52$ & - & $80.98 \pm 3.34$ & - & - \\
\hline Catechin & 280 & 9.46 & $23.12 \pm 0.92$ & $11.21 \pm 0.34$ & - & - & - & - \\
\hline Naringenin & 285 & 19.99 & - & - & - & $149.12 \pm 4.37$ & - & - \\
\hline Rutin & $\begin{array}{c}260-270 \\
360 \\
\end{array}$ & 13.2 & $87.34 \pm 1.12$ & - & $124.56 \pm 4.54$ & - & $67.89 \pm 2.35$ & - \\
\hline Myricetin & $255 ; 370$ & 15.78 & $84.67 \pm 2.92$ & $34.56 \pm 1.67$ & $89.67 \pm 1.64$ & $47.80 \pm 1.26$ & $131.89 \pm 4.46$ & $56.78 \pm 3.44$ \\
\hline Sinapic acid & $235 ; 320$ & 13.47 & $19.07 \pm 0.72$ & - & $99.12 \pm 2.34$ & - & $82.34 \pm 3.45$ & - \\
\hline p-coumaric acid & 310 & 12.47 & $71.56 \pm 1.97$ & $64.34 \pm 1.46$ & $89.23 \pm 1.24$ & $76.89 \pm 5.37$ & $102.34 \pm 6.37$ & $29.07 \pm 0.39$ \\
\hline Caffeic acid & 320 & 10.55 & - & $40.67 \pm 2.35$ & - & $72.67 \pm 4.67$ & - & - \\
\hline Ferulic acid & 320 & 13.51 & $121.54 \pm 5.36$ & $87.65 \pm 3.42$ & $77.76 \pm 2.35$ & $45.78 \pm 2.74$ & $129.89 \pm 5.31$ & $100.78 \pm 4.58$ \\
\hline Vanillic acid & $259 ; 292$ & 10.4 & $14.67 \pm 0.52$ & $12.78 \pm 0.39$ & - & - & - & - \\
\hline Syringic acid & 274 & 11.1 & - & $30.78 \pm 1.93$ & - & - & - & - \\
\hline
\end{tabular}

*Results are expressed as mean \pm standard deviation

The presence of luteolin, syringic acid and caffeic acid only in the second extract is suggesting the release of these compounds from their corresponding glycosylated forms. The highest quantity of polyphenolic compounds can be found in Viola wittrockiana Gams., Viola odorata L. presents the largest variety of phenolic acids and flavonoids.
The polyphenols, flavonoids content and the antioxidant capacity

The total phenolic and flavonoid content and the antioxidant capacity of the samples, measured by different complementary assays are shown in Table II.

Table II

The total polyphenols, flavonoids and the antioxidant capacity of samples

\begin{tabular}{|c|c|c|c|c|}
\hline No. & Methods & Viola odorata L. & Viola tricolor L. & Viola wittrockiana Gams. \\
\hline 1. & Total Polyphenols $(\mathrm{mg}$ GAE/100g DW) & $434.14 \pm 3.01$ & $445.03 \pm 0.12$ & $485.48 \pm 0.53$ \\
\hline 2. & Flavonoids $(\mathrm{mg} \mathrm{QE} / \mathrm{mL})$ & $1.40 \pm 0.32$ & $2.69 \pm 0.17$ & $3.96 \pm 0.28$ \\
\hline 3. & DPPH \% & $14.49 \pm 2.81$ & $74.34 \pm 2.64$ & $44.58 \pm 3.15$ \\
\hline 4. & FRAP $(\mathrm{mg}$ Trolox/mL) & $17.14 \pm 2.01$ & $14.71 \pm 1.41$ & $214.09 \pm 0.91$ \\
\hline 5. & CUPRAC $(\mathrm{mmol}$ Trolox/100 g) & $1.72 \pm 1.81$ & $2.68 \pm 1.74$ & $5.63 \pm 0.94$ \\
\hline
\end{tabular}

*Results are expressed as mean \pm standard deviation

The polyphenolic content of the three studied species was almost identical, being slightly increased for the Viola wittrockiana Gams. flowers (485.48 $\pm 0.53 \mathrm{mg}$ $\mathrm{GAE} / 100 \mathrm{~g} \mathrm{DW})$. The flavonoid content was three times higher for the Viola wittrockiana Gams. flowers $(3.96 \pm 0.28 \mathrm{mg} \mathrm{QE} / \mathrm{mL})$ compared to the Viola odorata $\mathrm{L}$. flowers $(1.40 \pm 0.32 \mathrm{mg} \mathrm{QE} / \mathrm{mL})$.

The antioxidant capacity of Viola flowers was tested by measuring their free radical scavenging activity. The highest flavonoid content was recorded for Viola wittrockiana Gams. flowers extract, with similar polyphenolic content floral the samples.

The highest DPPH inhibition was observed for the Viola tricolor flowers extract. Therefore, increased activity for these tests also suggests that anthocyanins and phenols present in Viola species flowers play an important role as antioxidants [11, 24].

The highest antioxidant activity was measured for Viola wittrockiana Gams. through the CUPRAC and Trolox assays.

The comparative study complements the specialty literature so that the antioxidant activity of the three
Viola species offers the possibility of their use in therapy after a correct identification [7, 27, 28, 38].

\section{Conclusions}

On a macroscopic level, especially at the beginning of the flowers period, the studied species may be easily confused, but microscopic analysis proved differences in the main stems. Such observations can contribute to the correct systematic classification of the species.

The physico-chemical characterization of the studied species indicated that Viola species has relatively high antioxidant activity in flowers.

The substances with antioxidant capacity were accumulated in large quantities in the studied flowers, compared with other plants [21,22].

Our results have shown that the Viola witrockiana Gams. flowers can be used as a source of natural antioxidants in pharmaceutical compounds, food processing and human and food medicine. 


\section{Acknowledgement}

The present work was supported by grants from The Ministry of Hungary Domus Hungarica 2016.

\section{References}

1. Benzie IF, Strain JJ, The ferric reducing ability of plasma (FRAP) as a measure of "antioxidant power". The FRAP assay. Anal Biochem., 1996; 239: 70-76.

2. Brand-Williams W, Cuvelier ME, Berset C, Use a free radical method to evaluate antioxidant activity. LWT-Food Sci Technol., 1995; 28: 25-30.

3. Duke JA, Bogenschutz-Godwin MJ, Ducelliar J, Duke PAK, Sweet Violet (Viola odorata L.), Handbook of Medicinal Herbs. $2^{\text {nd }}$ edition Boca Raton: CRC Press, 2002; 715.

4. Ebrahimzadeh MA, Nabavi SM, Nabavi SF, Bahramian F, Bekhradnia AR, Antioxidant and free radical scavenging activity of $H$. officinalis L. var. angustifolius, $V$. odorata, B. hyrcana and C. Speciosum. Pak J Pharm Sci., 2010; 23: 29-34.

5. El Gharras H, Polyphenols: food sources, properties and applications: a review. Int J Food Sci Tech., 2009; 44(12): 2512-2518.

6. Feng $\mathrm{Y}$, Wang $\mathrm{X}$, Antioxidant therapies for Alzheimer's disease. Oxid Med Cell Longev., 2012; 2012: 1-17.

7. Feyzabadi Z, Ghorbani F, Vazani Y, Zarshenas MM, A critical review on phytochemistry, pharmacology of Viola odorata L. and related multipotential products in traditional Persian medicine. Phytother Res., 2017; 31(11): 1669-1675.

8. Gamsjaeger S, Baranska M, Schulz H, Heiselmayer $\mathrm{P}$, Musso M, Discrimination of carotenoid and flavonoid content in petals of pansy cultivars (Viola wittrockiana) by FT-Raman spectroscopy. J Raman Spectrosc., 2011; 42(6): 1240-1247.

9. Ghorbani A, Asadpour E, Sadeghnia HR, Mechanism of protective effect of lettuce against glucose/serum deprivation induced neurotoxicity. Nutr Neurosci., 2015; 18: 103-109.

10. Ghorbani A, Hadjzadeh MR, Rajaei Z, Zendehbad $\mathrm{SB}$, Effects of fenugreek seeds on adipogenesis and lipolysis in normal and diabetic rat. Pak J Biol Sci., 2014; 17: 523-528

11. Ghorbani A, Youssofabad NJ, and Rakhshandeh H, Effect of Viola tricolor on pentobarbital-induced sleep in mice. Afr J Pharm Pharmacol., 2012; 6: 2503-2509.

12. Han X, Shen T, Lou H, Dietary polyphenols and their biological significance. Int J Mol Sci., 2007; 8(9): 950-988.

13. Hanganu D, Benedec D, Vlase L, Olah NK, Damian G, Silaghi Dumitrescu R, Mot A, Toma CC, Polyphenolic profile and antioxidant and antibacterial activities from two Trifolium species. Farmacia, 2017; 65(3): 449-453.

14. Hansel R, Keller R, Rimpler H, Schneider G, Hagers Handbuch der Pharmazeutischen Praxis, SpringerVerlag, Berlin, 1993; 34-39.

15. Ignat I, Volf I, Popa VI, A critical review of methods for characterisation of polyphenolic compounds in fruits and vegetables. Food Chem., 2011; 126(4): 1821-1835.

16. Ivănescu B, Tuchiluș C, Corciovă A, Lungu C, Mihai CT, Gheldiu A-M, Vlase L, Antioxidant, antimicrobial and cytotoxic activity of Tanacetum vulgare, Tanacetum corymbosum and Tanacetum macrophyllum extracts. Farmacia, 2018; 66(2): 282-288.

17. Jurca T, Marian E, Tita B, Vicas S, Pallag A, Toth I, Krusper L, Braun M, Vicas L, Determination of oligoelements content of plant material and assessment of bioactive compounds from Calendula officinalis lyophilized extract. Rev Chim (Bucharest), 2017; 68(8): 1786-1789.

18. Jurca T, Vicaș L, Marian E, Vicaş S, Mureșan M, A New natural antioxidant supplement - Design and development. Farmacia, 2016; 64(1): 135-142.

19. Kaisoon O, Siriamornpun S, Weerapreeyakul N, Meeso N, Phenolic compounds and antioxidant activities of edible flowers from Thailand. $J$ Funct Foods, 2011; 3(2): 88-99.

20. Karioti A, Furlan C, Vincieri FF, Bilia AR, Analysis of the constituents and quality control of Viola odorata aqueous preparations by HPLC-DAD and HPLC-ESI-MS. Anal Bioanal Chem., 2011; 399(4): 1715-1723.

21. Keville K, Viola odorata L. In Illustrated Herb Encyclopedia. Edited by: Rosart S. New York. Michael Friedman Publishing Group, Inc., 1991; 207.

22. Khattak SG, Gilani SN, Ikram M, Antipyretic studies on some indigenous Pakistani medicinal plants. $J$ Ethnopharmacol., 1985; 14: 45-51.

23. Kim D, Chun O, Kim Y, Moon H, Lee C, Quantification of polyphenolics and their antioxidant capacity in fresh plums. J Agric Food Chem.., 2003; 51: 6509-6515.

24. Koochek MH, Pipelzade MH, Mardani H, The effectiveness of Viola odorata in the prevention and treatment of formalin-induced lung damage in the rat. J Herbs, Spices Med Plants, 2003; 10: 95-103.

25. Kukrić Z, Topalić-Trivunović L, Pavičić S, Žabić M, Matoš S, Davidović A, Total phenolic content antioxidant and antimicrobial activity of Equisetum arvense L. Chem Ind Chem Eng Q., 2013; 19(1): 37-43.

26. Mlcek J, Rop O, Fresh edible flowers of ornamental plants - A new source of nutraceutical foods. Trends Food Sci Technol., 2011; 22(10): 561-569.

27. Mortazavian SM, Ghorbani A, Hesari TG, Effect of hydro-alcoholic extract of Viola tricolor and its fractions on proliferation of uterine cervix carcinoma cells. Ir J Obstet Gynecol Infertil., 2012; 15: 9-16.

28. Mortazavian SM, Ghorbani A, Antiproliferative effect of Viola tricolor on neuroblastoma cells in vitro. Australian J Herbal Med., 2012; 24: 93-96.

29. Naczk M, Shahidi F, Phenolics in cereals, fruits and vegetables: occurrence, extraction and analysis. $J$ Pharma Biomed Anal., 2006; 41(5): 1523-1542.

30. Pallag A, Filip GA, Olteanu D, Clichici S, Baldea I, Jurca T, Micle O, Vicaș L, Marian E, Sorițău O, Cenariu M, Mureşan M, Equisetum arvense L. extract induces antibacterial activity and modulates oxidative stress, inflammation, and apoptosis in endothelial vascular cells exposed to hyperosmotic stress. Oxid Med Cell Longev., 2018; 2018: 1-14. 
31. Pallag A, Jurca T, Sirbu V, Honiges A, Jurca C, Analysis of the amount of polyphenols, flavonoids and assessment of the antioxidant capacity of frozen fruits. Rev Chim (Bucharest), 2018; 69(2): 445-448.

32. Pallag A, Jurca T, Pasca B, Sirbu V, Honiges A, Costuleanu M, Analysis of phenolic compounds composition by HPLC and assessment of antioxidant capacity in Equisetum arvense L. extracts. Rev Chim (Bucharest), 2016; 67(8): 1623-1627.

33. Pallag A, Paşca B, Jurca T, Suciu R, Nemeth S, Vicaş $\mathrm{L}$, Comparative histo-anatomical researches on the vegetative organs and assessment of antioxidant capacity of two species from Equisetum genus. Farmacia, 2016; 64(3): 372-377.

34. Rice-Evans CA, Miller NJ, Paganga G, Antioxidant properties of phenolic compounds. Trends Plant Sci., 1997; 2: 152-159.

35. Santas J, Almajano MP, Carbó R, Antimicrobial and antioxidant activity of crude onion (Allium cepa $\mathrm{L}$.) extracts. Int J Food Sci Tech., 2010; 45(2): 403-409.

36. Škerget M, Kotnik P, Hadolin M, Hraš AR, Simonič M, Knez Ž, Phenols, proanthocyanidins, flavones and flavonols in some plant materials and their antioxidant activities. Food Chem., 2005; 89(2): 191-198.

37. Stojković D, Glamočlija J, Ćirić A, Šiljegović J, Nikolić M, Soković M, Free radical scavenging activity of Viola odorata water extracts. J Herbs Spices Med Plants, 2011; 17: 285-290.

38. Toiu A, Muntean E, Oniga L, Vostinaru O, Tamas M, Pharmacognostic research on Viola tricolor L.
(Violaceae). Rev Med Chir Soc Med Nat Iasi, 2009; 113: 246-247.

39. Vicaș L, Teușdea A, Vicaș S, Marian E, Jurca T, Mureşan M, Gligor F, Assessment of antioxidant capacity of some extracts for further use in therapy. Farmacia, 2015; 63(2): 267-274.

40. Vishal A, Parveen K, Pooja S, Kannappan N, Kumar $\mathrm{S}$, Diuretic, laxative and toxicity studies of Viola odorata aerial parts. Pharmacol online, 2009; 1: 739-748.

41. Vukics V, Kery A, Bonn GK, Guttman A, Major flavonoid components of heartsease (Viola tricolor L.) and their antioxidant activities. Anal Bioanal Chem., 2008; 390: 1917-1925.

42. Vukics V, Kery A, Guttman A, Analysis of polar antioxidants in heartsease (Viola tricolor L.) and garden pansy (Viola wittrockiana Gams.). J Chromat Sci., 3008; 46: 823-827.

43. Witkowska-Banaszczak E, Bylka W, Matlawska I, Goslinska O, Muszynski Z, Antimicrobial activity of Viola tricolor herb. Fitoterapia, 2005; 76: 458-461.

44. Yuan W, Zhou LJ, Deng GR, Wang P. Creech D, Li SY, Anthocyanins, phenolics and antioxidant capacity of Vaccinium L. in Texas, USA. Pharm C., 2011; 2: 11-13.

45. Zia-Ul-Haq M, Ahmad S, Stankovici MS, Sultan MT, Imran I, Velter V, Badiu D, Halichidis S, Hangan T, Antimicrobial and antioxidant potential if Ipomoea hedereacea. Farmacia, 2014; 62(6): 1181-1190. 